\title{
Penentuan Target, Strategi dan Faktor- Faktor yang Mempengaruhi Optimalisasi Pajak Daerah
}

\section{Affiliation: \\ Universitas Riau, Indonesia \\ *Correspondence: \\ yesimutia@gmail.com \\ This Article is Avalilable in: \\ https://journal.umy.ac.id/index.php/jat i/article/view/10394}

DOI:

https://doi.org/10.18196/jati.v4i2.103 94

Citation:

Effendi, F., Ratnawati, V., \& Basri, Y. (2021). Penentuan Target, Strategi dan Faktor-Faktor yang Mempengaruhi Optimalisasi Pajak Daerah. Jati: Jurnal Akuntansi Terapan Indonesia, 4(2), 95116.

\section{Article History}

Received:

27 November 2020

Reviewed:

24 December 2020

Revised:

31 December 2020

Accepted:

15 April 2021

Topic Article:

Perpajakan

\author{
Fauzan Effendi, Vince Ratnawati, Yesi Mutia Basri*
}

\begin{abstract}
:
The research aimed to analyze the suitability of local tax target setting with real potential, analyze strategies and factors that influence the optimization of the advertisement tax performance, swallow's nest tax, groundwater tax, and Non-Metal Mineral Tax in Pekanbaru City. The object of this study is the Pekanbaru City Regional Revenue Agency and four objects/subjects of local taxes studied in Pekanbaru City. The method used is qualitative with a case study approach. This research shows that the target setting of Advertising Tax, Swallow's Nest Tax, Groundwater Tax, and Non-Metal Mineral and Rock Tax has not been adjusted to the real potential. The performance reports of each Regional Tax studied were inadequate in relation to the strategies implemented, which made it difficult for the Regional Revenue Agency to make effective and efficient decisions. The factors that influence tax optimization are the inadequate organizational structure, updating of the taxation database, human resources, the use of information technology, strengthening regulations, and supporting infrastructure.
\end{abstract}

Keywords: Local Tax, Target, Strategy, Constraints.

\begin{abstract}
Abstrak:
Penelitian bertujuan untuk menganalisis kesesuaian penetapan target pajak daerah dengan potensi ril, menganalisis strategi dan faktor-faktor yang mempengaruhi optimalisasi kinerja Pajak Reklame, Pajak Sarang Burung Walet, Pajak Air Tanah; dan Pajak Mineral Bukan Logam di Kota Pekanbaru. Objek Penelitian ini adalah Aparatur Badan Pendapatan Daerah Kota Pekanbaru dan 4 objek/ Subjek pajak daerah yang diteliti di Kota Pekanbaru. Metode yang digunakan adalah kualitatif dengan pendekatan studi kasus. Penelitian ini menunjukkan bahwa penetapan target Pajak Reklame, Pajak Sarang Burung Walet, Pajak Air Tanah; dan Pajak Mineral Bukan Logam dan batuan belum disesuaikan dengan potensi ril. Laporan kinerja masing-masing Pajak Daerah yang diteliti belum memadai terkait strategi yang telah dilakukan sehingga menyulitkan Badan Pendapatan Daerah dalam pengambilan keputusan yang efektif dan efisien. Faktor-faktor yang mempengaruhi optimalisasi pajak tersebut adalah belum memadainya struktur organisasi, pemutakhiran data base perpajakan, kondisi Sumber Daya Manusia, pemanfaatan teknologi informasi, Penguatan Regulasi dan sarana prasarana pendukung.
\end{abstract}

Kata Kunci: Pajak Daerah, Target, Strategi, Kendala

\section{PENDAHULUAN}

Undang-Undang Nomor 23 Tahun 2014 tentang Pemerintahan Daerah telah mendistribusikan otonomi yang seluas-luasnya kepada Daerah untuk mempercepat terciptanya 
kesejahteraan masyarakat yang diikuti dengan pelimpahan sumber-sumber keuangan salah satunya melalui Pajak Daerah (Indonesia, 2014). Posisi strategis pajak daerah tersebut diatur dalam Undang-Undang Nomor 28 tahun 2009 tentang Pajak Daerah dan Retribusi Daerah yang mendorong Pajak Daerah sebagai sumber pendanaan terbesar dalam pembiayaan pembagunan di Daerah (Undang-Undang Nomor 28 Tahun 2009 Tentang Pajak Daerah Dan Retribusi Daerah, 2009).

Salah satu indikator tingkat kemandirian daerah (Ritonga, 2017) dapat dilihat dari kemampuan suatu pemerintah daerah dalam menghasilkan Pendapatan Asli Daerah (yang salah satu komponennya adalah Pajak Daerah) dibandingkan dengan total pendapatan atau yang juga disebut dengan istilah Derajat Otonomi Fiskal. Berdasarkan data dari Direktorat Jenderal Perimbangan Keuangan Daerah Kementerian Keuangan, pada tahun 2018 rata-rata dominasi dana perimbangan dari Pemerintah Pusat dalam pendapatan APBD ditingkat Kabupaten dan/ ataupun Kota sebesar 67\% dan Daerah Provinsi sebesar sebesar $47 \%$ terhadap total pendapatan daerah (Keuangan (DJPK), 2018). Data ini menunjukkan bahwa Daerah masih sangat bergantung kepada Pemerintah Pusat melalui Dana Perimbangan yang artinya belum terlihat eksistensi pajak daerah sebagai salah satu sumber Pendapatan Asli Daerah (PAD) yang diharapkan sebagai tonggak kemandirian keuangan daerah.

Meskipun tren penerimaan Pajak Daerah meningkat dari tahun ke tahun (years to years), Kota Pekanbaru tidak pernah mencapai target pajak daerah sebagaimana yang telah ditetapkan selama 6 tahun terakhir (2014-2019).

Tabel 1. Perbandingan Target dengan Nilai Realisasi Pajak Daerah di Bapenda Kota Pekanbaru (2014 - 2019)

\begin{tabular}{|c|c|c|c|c|c|c|}
\hline \multirow[t]{2}{*}{ No } & \multirow[t]{2}{*}{ Tahun } & \multirow[t]{2}{*}{ Target Pajak Daerah } & \multirow{2}{*}{$\begin{array}{l}\text { Realisasi Pajak } \\
\text { Daerah (Rp) }\end{array}$} & \multirow{2}{*}{$\begin{array}{c}\% \\
\text { Realisasi }\end{array}$} & \multicolumn{2}{|c|}{$\begin{array}{l}\text { Perbandingan Dengan } \\
\text { Tahun sebelumnya }\end{array}$} \\
\hline & & & & & Target & Realisasi \\
\hline 1 & 2 & 3 & 4 & 5 & *6 & $* * 7$ \\
\hline 1 & 2019 & $784,882,467,046$ & $620,937,643,530$ & $79,11 \%$ & $-1,92 \%$ & $19,56 \%$ \\
\hline 2 & 2018 & 799.950 .540 .000 & 499.490 .899 .787 & $62,44 \%$ & $2,13 \%$ & $1,67 \%$ \\
\hline 3 & 2017 & 783.260 .371 .972 & 491.289 .420 .935 & $62,72 \%$ & $45,67 \%$ & $25,87 \%$ \\
\hline 4 & 2016 & 537.699 .455 .844 & 390.323 .492 .884 & $72,59 \%$ & $-11,44 \%$ & $9,22 \%$ \\
\hline 5 & 2015 & 607.142 .075 .491 & 357.365 .343 .616 & $58,86 \%$ & $78,22 \%$ & $22,83 \%$ \\
\hline 6 & 2014 & 340.662 .396 .642 & 290.932 .820 .954 & $85,40 \%$ & & \\
\hline
\end{tabular}

* Target Tahun berjalan/ Target Tahun Sebelumnya

** Realisasi tahun berjalan/ realisasi tahun sebelumnya

Sumber: Badan Pendapatan Daerah Kota Pekanbaru/Diolah

Konsistensi yang kurang memadai dari 4 jenis pajak daerah yaitu Pajak Reklame, Pajak Air Tanah, Pajak Sarang Burung Walet dan Pajak Mineral bukan Logam dan Batuan telah berimplikasi buruk terhadap capaian Pajak Daerah untuk selanjutnya berkontribusi negatif kepada total Pendapatan Asli Daerah dan Pendapatan Daerah secara keseluruhan. Berdasarkan data dari Badan Pendapatan Daerah Kota Pekanbaru, dari target penerimaan pajak yang ditetapkan sesuai APBD tahun 2014 - 2019, angka realisasinya hanya berkisar 10 s.d 24 \%-an untuk Pajak Reklame; 0.06 s.d 4.24 \%an untuk Pajak Mineral Bukan Logam dan batuan; 2 s.d 43,08 \%an untuk Pajak air tanah dan 1 sampai 6 \%an untuk Pajak Sarang Burung Walet. 
Effendi, Ratnawati, Basri

Penentuan Target, Strategi dan Faktor-Faktor yang Mempengaruhi

Optimalisasi Pajak Daerah

Tabel 2. Persentase Realisasi Pajak Daerah Kota Pekanbaru (2014- 2019)

\begin{tabular}{|c|c|c|c|c|c|c|c|}
\hline \multirow{2}{*}{ No } & \multirow{2}{*}{ Jenis Pajak Daerah } & \multicolumn{6}{|c|}{ \% Realisasi Pajak Daerah pada Tahun } \\
\hline & & 2014 & 2015 & 2016 & 2017 & 2018 & 2019 \\
\hline 1 & Pajak Hotel & 95,57 & 51,23 & 95,12 & 33,72 & 105.18 & 100.09 \\
\hline 2 & Pajak Restoran & 106,96 & 71,62 & 95,91 & 101,90 & 102.39 & 101.32 \\
\hline 3 & Pajak Hiburan & 100,54 & 38,84 & 65,08 & 100,19 & 99.49 & 100.43 \\
\hline 4 & Pajak Reklame & 23,63 & 12,94 & 22,24 & 12,02 & 10.52 & 20.90 \\
\hline 5 & Pajak Penerangan Jalan Umum & 104,14 & 103,21 & 106,21 & 101,46 & 101.70 & 100.46 \\
\hline 6 & $\begin{array}{c}\text { Pajak Mineral Bukan Logam } \\
\text { dan Batuan }\end{array}$ & 4,24 & 1,64 & 0,57 & 0,16 & 0.27 & 0.06 \\
\hline 7 & Pajak Parkir & 101,53 & 54,10 & 81,22 & 110,97 & 100.74 & 100.66 \\
\hline 8 & Paja Air Bawah Tanah & 43,08 & 14,53 & 16,13 & 2,78 & 7.97 & 11.90 \\
\hline 9 & Pajak Sarang Burung Walet & 5,70 & 1,70 & 1,53 & 0,13 & 0.13 & 1.23 \\
\hline 10 & $\begin{array}{c}\text { Bea Perolehan Ha katas Tanah } \\
\text { dan Bangunan }\end{array}$ & 98,47 & 109,27 & 94,02 & 135,19 & 110.54 & 93.08 \\
\hline \multirow[t]{2}{*}{11} & PBB Sektor Perkotaan & 81,16 & 45,71 & 58,00 & 33,72 & 34.79 & 102.04 \\
\hline & Total Pajak Daerah & 85,40 & 58,86 & 72,59 & 62,72 & 62,44 & 79,11 \\
\hline
\end{tabular}

Sumber: Badan Pendapatan Daerah Kota Pekanbaru/Diolah

Langkah-langkah strategis perlu dilakukan Badan Pendapatan Daerah Kota Pekanbaru sebagai leading sector di bidang perpajakan daerah di Kota Pekanbaru untuk mengejar target penerimaan pajak terhadap jenis-jenis pajak daerah yang diperkirakan tidak akan dapat mencapai target yang ditentukan seperti Pajak Reklame, Pajak Air Tanah, Pajak Sarang Burung Walet dan Pajak Mineral bukan Logam dan Batuan. Kementerian Dalam Negeri Republik Indonesia sebagai Pembina dari Pemerintah Daerah setiap tahunnya juga menerbitkan Peraturan tentang Pedoman Penyusunan APBD yang mana salah satunya mengatur tentang penetapan target pajak daerah dalam APBD (Kemendagri, 2019). Berdasarkan panduan tersebut menyebutkan bahwa penetapan target pajak daerah harus didasarkan pada data potensi pajak daerah di masing-masing pemerintah provinsi dan pemerintah Kabupaten/kota dengan memperhatikan perkiraan pertumbuhan ekonomi pada tahun tersebut yang berpotensi terhadap target pendapatan pajak daerah.

Hasil penelitian terdahulu menunjukkan penghambat optimalisasi penerimaan pajak reklame adalah kurangnya sumber daya, kurangnya sarana dan prasarana seperti teknologi, kendaraan dinas serta alat-alat yang mempermudah dalam menjalankan tugas dan tingkat kesadaran pelaku usaha sebagai wajib pajak yang masih rendah (Affriani, 2018). Selanjutnya (M. T. Sari, 2018) Optimalisasi Pemungutan Pajak Daerah di Provinsi Lampung juga menambahkan bahwa terdapat beberapa kendala dalam optimalisasi pemungutan pajak daerah yang terlihat pada: Pendataan potensi pajak, Pengawasan, Koordinasi dan Srategi Pemungutannya.

Peneliti-peneliti terdahulu sudah memulai penelitian dengan topik optimalisasi pajak dan pajak daerah (Adelina, 2013; Affriani, 2018; Alisman, 2015; Asteria, 2015; Harly \& Afriyenty, 2017; Hildawati, 2016; Mandala Harefa, Sony Hendra Permana, Dewi Restu Mangeswuri, 2017; Nikho, 2010; Putra, 2010; Putri, 2013; Riduansyah, 2003; Saputro, 2018; D. P. Sari \& Ilyas, 2019; M. T. Sari, 2018; Tahwin, 2013; Wardhani, 2016; Wardhono et al., 2012; Wijayanti, 2010), namun sejauh ini penelitian terdahulu sangat terbatas membahas bagaimana penentuan target pajak disuatu daerah. Penelitian ini mencoba mengupas permasalahan dari hulu yaitu mulai dari sisi perencanaan dalam penetapan target pajak daerah sehingga dapat ditemui integrasi antara optimalisasi upaya dan strategi dengan permasalahan yang ada sehingga dihilirnya tercipta realisasi kinerja pajak daerah yang 
optimal. Perbedaan lainnya adalah terkait lokasi fokus penelitian serta kedalaman penelitiannya. Bahwasanya pajak daerah merupakan pajak yang disesuaikan dengan karakteristik masing-masing daerah Kabupaten/ kota yang ada di Indonesia, misalnya daerah $\mathrm{A}$ tidak akan sama dengan daerah $\mathrm{B}$ begitu seterusnya.

Selain berkontribusi dalam bidang ilmu sektor publik, penelitian ini memiliki kontribusi bagi pemerintah daerah yaitu dapat menjadi bahan pertimbangan dalam merumuskan kebijkan dalam peningkatan potensi pajak daerah.

\section{METODE PENELITIAN}

Penelitian ini adalah penelitian kualitatif dengan pendekatan studi kasus. Diamond dan Holloway (2008) menyebutkan pada umumnya studi kasus dihubungkan dengan sebuah lokasi atau sebuah organisasi, sekumpulan orang seperti kelompok kerja atau kelompok sosial, peristiwa, proses, isu maupun kampanye (Gunawan, 2015). Penelitian studi kasus termasuk dalam penelitian kualitatif, oleh karena itu temuan atau hasil penelitiannya tidak dapat diramalkan karena penelitian kualitatif tidak mempunyai prosedur yang baku. Dengan demikian data yang diperoleh tidak bisa diramalkan karena ia banyak bergantung kepada peserta penelitian. Hal ini adalah sebagaimana dimaksud dalam tujuan penelitian yang telah dilakukan oleh Creswell, 1994: Merriam, 1994 dan Roslan, 2002 (Afrizal, 2015). Justru penelitian kasus berasaskan metode kualitatif yang menggabungkan instrument wawancara dan pengamatan serta analisis dokumen, wajar dilakukan apabila peserta penelitian yang hendak diteliti sedikit. Ini karena dalam penelitian kasus dilakukan secara mendalam dan terperinci (holistic) (Tohirin, 2016). Pendekatan studi kasus dimaksudkan supaya peneliti mampu melihat objek penelitian secara mendalam terkait penetapan target pajak reklame, air tanah, sarang burung wallet dan mineral bukan logam dan batuan di Kota Pekanbaru dan pengungkapan sejauh mana upaya-upaya yang telah dilakukan dan faktorfaktor kendala yang dihadapi Badan Pendapatan Daerah Kota Pekanbaru sebagai leading sector pengelolaan pajak daerah di Kota Pekanbaru.

Penelitian dilakukan pada tahun 2020. Penentuan informan adalah menggunakan metode purposive dengan pertimbangan tertentu yang artinya teknik penentuan informan dimana peneliti mengandalkan penilaiannya sendiri Ketika memilih informan untuk berpartisipasi dalam penelitian ini. Selain itu "karena orang-orang tertentu yang dianggap paling tahu tentang apa yang peneliti harapkan atau mungkin sampel memiliki kekuasaan sehingga akan memudahkan peneliti menjelajahi objek/ situasi sosial yang diteliti" (Sugiyono, 2012). Pertimbangan dalam memilih informan adalah informan yang memiliki jabatan terkait dengan penganggaran pajak daerah. Informan yang dipilih adalah Pejabat struktural BPKAD Kota Pekanbaru untuk mendalami informasi-informasi untuk menjawab pertanyaan penelitian yang ke-1 (satu) tentang proses penetapan target pajak daerah yang merupakan bagian dari proses penetapan APBD dan Badan Pengelolaan Keuangan Daerah (BPKAD) adalah Organisasi Perangkat Daerah leading sector yang melakukan kegiatan penganggaran dimaksud, Badan pendapatan Daerah Kota Pekanbaru sebagai Organisasi Perangkat Daerah (OPD) yang memilik tugas pokok dan fungsi sebagai penyelenggara urusan penunjang bidang pendapatan pajak daerah di Kota Pekanbaru, Akademisi/ ahli pemerintahan daerah sebagai informan independent yang diharapkan mampu melihat secara netral dan memberikan kontribusi yang relevan sesuai keahliannya dan Wajib Pajak Air Tanah dan Reklame sebagai pihak yang berkaitan langsung atas operasionalisasi kegiatan optimalisasi pajak daerah yang diteliti.

Teknik-teknik pengumpulan data dalam penelitian ini meliputi:

1. Pengamatan langsung ke lokasi penelitian yaitu (1) Badan Pendapatan Daerah 
Kota Pekanbaru; (2) Lokasi Wajib Pajak yang menjadi Objek Penelitian.

2. Data melalui wawancara dimulai dengan objektivitias penentuan seseorang menjadi informan penelitian didasarkan pada kriteria kedudukan, peran, kompetensi atau keterlibatan yang relevan atau terkait dengan proses pengungkapan dan pembahasan implementasi kebijakan Pajak Reklame, Pajak Air Bawah Tanah, Pajak Sarang Burung Walet dan Pajak Mineral Bukan Batuan dan Logam.

3. Pengumpulan data dengan dokumen dapat berbentuk tulisan, gambar atau data statistik lainnya. Hasil data dari observasi ataupun wawancara akan lebih kredibel/ dapat dipercaya apabila didukung oleh dokumentasi (Sugiyono; 422).

4. Selanjutnya Peneliti menggunakan trianggulasi berarti peneliti menggunakan observasi, wawancara dan dokumentasi untuk sumber data yang sama secara serempak.

Menurut Miles \& Hubberman (1984), Marshal \&Rossman (1995) dan Bodgan \& Biklen (1992) dalam Tohirin $(2016 ; 26)$; proses penganalisisan data kualitatif terbagi dalam dua tahap yaitu ketika dan setelah proses pengumpulan data.

Pertama, ketika proses pengumpulan data harus terdokumentasi dalam media yang memadai untuk memudahkan proses analisis selanjutnya (Moleong, 2019). Kedua, Setelah data terangkum dalam media yang memadai selesai dilakukan, data dimaksud dianalisis mengikuti tujuh tahapan (Tohirin, 2016) yaitu:

1. Merangkum semua data dalam media yang memadai untuk diterjemahkan dalam bentuk deskriptif atau transkrip wawancara.

2. Proses reduksi, yaitu memberikan kembali kepada informan untuk menyemak jika terdapat hal-hal yang perlu direvisi atau ditambah dalam transkrip wawancara tersebut.

3. Peneliti membangun tema tentang fokus penelitiannya berdasarkan jawaban peserta penelitian.

4. Proses pemberian kode dapat melihat keseluruhan sesuatu tema yang dominan untuk mengenali dengan jelas keseluruhan tema dalam wawancara.

5. Operasionalisasi defenisi secara operasional setiap tema yang telah diuraikan.

6. Konfirmasi silang dengan data-data lainnya yang diperoleh melalui pengamatan langsung, dokumen dan/ ataupun triangulasi.

7. Proses penulisan laporan tersebut dibuat secara deskriptif mengikuti tema dalam beberapa konteks.

\section{HASIL DAN PEMBAHASAN}

\section{Pelaksanaan Penelitian dan dan Informan Penelitian}

Berdasarkan Surat Rekomendasi Penelitian dari Dinas Penanaman Modal dan Pelayanan Terpadu Satu Pintu (DPMPTSP) Provinsi Riau dengan Nomor 503/DPMPTSP/Non Izin-Riset/33538, peneliti langsung melakuan peninjauan lapangan guna mendapatkan dokumen dokumen pendukung dan menjajaki informan yang akan diwawancarai. Sehubungan dalam masa pandemic covid-19 yang menjadi isu paling strategis di Kota Pekanbaru dan dalam rangka ikut menyukseskan program pemerintah dalam pemutusan mata rantai penyebaran covid-19 di Kota Pekanbaru, beberapa kegiatan wawancara dalam penelitian ini dilakukan tanpa bertemu langsung dengan para informan. Untuk menjaga kerahasian identitas informan dalam setiap kutipan yang kami tampilkan menggunakan inisial dari nama informan yang bersangkutan. 
Effendi, Ratnawati, Basri

Penentuan Target, Strategi dan Faktor-Faktor yang Mempengaruhi

Optimalisasi Pajak Daerah

Tabel 3. Pelaksanaan Kegiatan Wawancara

\begin{tabular}{|c|c|c|c|c|}
\hline No & $\begin{array}{c}\text { Inisial } \\
\text { Informan }\end{array}$ & $\begin{array}{c}\text { Tanggal Wawancara dan Jam } \\
\text { Wawancara }\end{array}$ & Media Pelaksanan & Posisi Informan \\
\hline 1 & $\mathrm{AK}$ & 07 Juli 2020 & $\begin{array}{l}\text { Wawancara } \\
\text { langsung }\end{array}$ & $\begin{array}{c}\text { Pejabat struktural di } \\
\text { BPKAD Kota } \\
\text { Pekanbaru }\end{array}$ \\
\hline 2 & AL & $\begin{array}{c}01 \text { Juli } 2020 \text { Jam } 15.30-16.30 \\
\text { WIB }\end{array}$ & $\begin{array}{l}\text { Wawancara } \\
\text { Langsung }\end{array}$ & $\begin{array}{c}\text { Pejabat Struktural } \\
\text { Bapenda Kota } \\
\text { Pekanbaru }\end{array}$ \\
\hline 3 & $\mathrm{AR}$ & $\begin{array}{l}\text { 05 Juli } 2020 \text { Jam } 14.00-15.00 \\
\text { WIB }\end{array}$ & $\begin{array}{l}\text { Wawancara } \\
\text { langsung }\end{array}$ & $\begin{array}{c}\text { Akademisi/ Ahli } \\
\text { Pemerintahan Daerah }\end{array}$ \\
\hline 4 & $\mathrm{E}$ & $\begin{array}{l}\text { 04 Juli } 2020 \text { Jam } 16.00-17.00 \\
\text { WIB }\end{array}$ & $\begin{array}{l}\text { Via Telepon/ Audio } \\
\text { direkam }\end{array}$ & $\begin{array}{c}\text { Pejabat Struktural di } \\
\text { Bapenda Kota } \\
\text { Pekanbaru }\end{array}$ \\
\hline 5 & $\mathrm{~N}$ & O6 Juli 2020 & $\begin{array}{c}\text { Transkrip } \\
\text { Wawancara } \\
\text { dikirimkan via email }\end{array}$ & $\begin{array}{c}\text { Pejabat Struktural di } \\
\text { Bapenda Kota } \\
\text { Pekanbaru }\end{array}$ \\
\hline 6 & MIF & 02 Juli 2020 pukul 13.04 WIB & $\begin{array}{c}\text { Transkrip } \\
\text { Wawancara } \\
\text { dikirimkan via } \\
\text { Whats App }\end{array}$ & $\begin{array}{c}\text { Pejabat Struktural di } \\
\text { Bapenda Kota } \\
\text { Pekanbaru }\end{array}$ \\
\hline 7 & A & 01 Juli 2020 pukul 12.00 WIB & $\begin{array}{l}\text { Transkrip } \\
\text { Wawancara } \\
\text { dikirimkan via } \\
\text { Whats App }\end{array}$ & $\begin{array}{c}\text { Pejabat Struktural di } \\
\text { Bapenda Kota } \\
\text { Pekanbaru } 2015 \text { - } \\
2018\end{array}$ \\
\hline 8 & AI & $\begin{array}{c}\text { 09 September } 2020 \text { Pukul } 20.00 \\
\text { WIB }\end{array}$ & $\begin{array}{c}\text { Transkrip } \\
\text { Wawancara } \\
\text { dikirimkan via } \\
\text { WhatsApp }\end{array}$ & $\begin{array}{c}\text { Pelaksana Sub Bidang } \\
\text { Penagihan Bapenda }\end{array}$ \\
\hline 9 & $\mathrm{~F}$ & $\begin{array}{c}18 \text { Agustus } 2020 \text { Pukul } 21.00 \\
\text { WIB }\end{array}$ & $\begin{array}{l}\text { Wawancara melalui } \\
\text { Whats App }\end{array}$ & $\begin{array}{c}\text { Wajib Pajak Air } \\
\text { Bawah Tanah dan } \\
\text { Wajib Pajak Reklame }\end{array}$ \\
\hline
\end{tabular}

Selanjutnya untuk mendukung kevalidan informasi dari para informan peneliti juga mengumpulkan data dan/ ataupun informasi dari dokumen-dokumen terkait yaitu: Laporan Akuntabilitas Kinerja Instansi Pemerintah (LAKIP) Badan Pendapatan Daerah Kota Pekanbaru tahun 2018, Laporan Akuntabilitas Kinerja Instansi Pemerintah (LAKIP) Badan Pendapatan Daerah Kota Pekanbaru tahun 2019, Salinan Jumlah Wajib Pajak Reklame, Sarang Burung Walet, Air tanah dan Mineral bukan logam dan Batuan per 31 Desember 2019, Salinan daftar jumlah Pegawai Negeri Sipil per 31 Desember 2019, Salinan Peraturan Walikota Pekanbaru tentang Struktur Organisasi dan Tupoksi Badan Pendapatan Daerah Kota Pekanbaru, Himpunan Peraturan Daerah dan Peraturan Walikota Pekanbaru tentang Petunjuk Pelaksanaan Pemungutan Pajak Reklame, Air Tanah, Sarang Burung Walet dan Mineral bukan Logam dan batuan, Laporan Badan Pendapatan Daerah Kota Pekanbaru tahun 2017, Laporan Kinerja Penerimaan Pajak Daerah tahun 2015 s.d 2019, Dokumen peraturan Perundang-Undangan meliputi Undang-Undang Nomor 28 tahun 2009 tentang Pajak daerah dan Retribusi daerah dan Peraturan Pelaksanaan dibawahnya, Catatan Lapangan yang kami peroleh selama bekerja sebagai Aparatur Sipil Negara (ASN) di Badan Pendapatan Daerah Kota Pekanbaru, Dokumen Pembanding dari OPD/ instansi terkait misalnya Data Perizinan dan Non Perizinan dari Dinas Penanaman Modal dan Pelayanan Terpadu Satu Pintu (DPMPTSP) Kota Pekanbaru serta data sejenis lainnya. 


\section{Analisis Penentuan Target Pajak Pajak Reklame, Pajak Sarang Burung Walet, Pajak Air Tanah, dan Pajak Mineral Bukan Logam dan Batuan}

Berdasarkan pengamatan langsung oleh peneliti di Badan Pendapatan Daeraeh Kota Pekanbaru (Periode Pengamatan berlangsung pada September 2020 dalam rangkaian proses kegiatan Perubahan Anggaran APBD 2020 oleh Tim Anggaran APBD Kota Pekanbaru kepada seluruh SKPD di Lingkungan Pemerintah Kota Pekanbaru). Proses penetapan target pajak Reklame, Air Tanah, Sarang Burung Walet dan Mineral bukan Logam dan batuan mengikuti proses-proses baku dalam tahapan APBD yang telah ditetapkan dalam peraturan perundang-undangan karena pajak pajak tersebut merupakan sumber Pendapatan Daerah yang merupakan bagian dari struktur APBD sebagaimana dimaksud dalam Undang-Undang Nomor 28 tahun 2009 tentang Pajak Daerah dan Retribusi Daerah.

"Penentuan target pajak daerah adalah bagian dari struktur ABPD. Penyusunan APBD berpedoman kepada Rencana Kerja Pemerintah Daerah. Karena itu kegiatan pertama dalam penyusunan APBD adalah penyusunan Rencana Kerja Pemerintah Daerah (RKPD). Pemerintah daerah menyusun RKPD yang merupakan penjabaran dari Rencana Pembangunan Jangka Menengah Daerah (RPJMD) dengan menggunakan bahan dari Renja Satuan Kerja Perangkat Daerah (SKPD) ........". (IF5/PTPD/55).

Penganggaran pada Pemerintah Daerah Provinsi/Kabupaten/Kota diawali dengan penyusunan PPAS (Prioritas dan Plafon Anggaran Sementara) setelah diketahui informasi berapa ketersediaan anggaran. Artinya Pajak harus dioptimalkan sebagai the last effort yang memiliki pengertian bahwa pemerintah daerah harus mengupayakan pajak daerah yang sudah diatur dalam Undang-Undang Pajak Daerah dan Retribusi Daerah dengan menggunakan tolak ukur atau indikator (Mardiasmo, 2009) agar dapat menjadi sumber pendanaan yang memadai. Disisi lainnya Optimalisasi Kebijakan Penerimaan Daerah (Mandala Harefa, Sony Hendra Permana, Dewi Restu Mangeswuri, 2017) menyebutkan bahwa upaya-upaya agar penerimaan pajak daerah dapat lebih optimal dengan memanfaatkan potensi-potensi yang ada melalui intensifikasi dan ekstensifikasi penerimaan pajak daerah (penguatan dari internal dan eksternal organisasi) yang salah satunya adalah melalui memperluas basis penerimaan pajak dengan melakukan analisis sumber-sumber penerimaan baru yang dianggap potensial, antara lain dengan mengidentifikasi pembayar pajak baru/potensial dan jumlah pembayar pajak, memperbaiki basis data objek pajak, memperbaiki penilaian perhitungan pajak, menghitung kapasitas penerimaan dari setiap jenis pungutan.

Efektivitas adalah ukuran berhasil tidaknya suatu organisasi mencapai tujuannya (Mardiasmo, 2004) yang memiliki pengertian bahwa perbandingan atau rasio antara penerimaan dengan target pajak reklame yang telah ditetapkan setiap tahunnya berdasarkan potensi riil. Kemampuan Badan Pendapatan Daerah Kota Pekanbaru dalam merealisasikan penerimaan pajak daerah dibandingkan dengan target yang ditetapkan berdasarkan potensi sesungguhnya dapat ditunjukkan melalui rasio efektivitas. Efektivitas Pajak Reklame, Pajak Sarang Burung Walet, Pajak Air Tanah, dan Pajak Mineral Bukan Batuan dan Logam dihitung dengan membandingkan realisasi penerimaan dengan target atau anggaran yang direncanakan tiap tahunnya dengan rumus dan perhitungan (Simanjuntak dalam Halim 2004:93) sebagai berikut:

Efektivitas $=$ Realisasi Penerimaan Pajak $\times 100 \%$ Target Penerimaan Pajak berdasarkan potensi rill 
Effendi, Ratnawati, Basri

Penentuan Target, Strategi dan Faktor-Faktor yang Mempengaruhi

Optimalisasi Pajak Daerah

Tabel 4. Standar Efektivitas

\begin{tabular}{cc}
\hline Interval & Tingkat Efektivitas \\
\hline Diatas $100 \%$ & Sangat Efektif \\
$90 \%-100 \%$ & Efektif \\
$80 \%-90 \%$ & Cukup Efektif \\
$60 \%-80 \%$ & Kurang Efektif \\
Kurang dari $60 \%$ & Tidak Efektif \\
\hline
\end{tabular}

Sehingga Efektivitas pajak daerah yang diteliti adalah:

Tabel 5. Efektivitas Pajak Daerah di Kota Pekanbaru

\begin{tabular}{|c|c|c|c|c|c|c|}
\hline \multirow{2}{*}{ No } & \multirow{2}{*}{ Jenis Pajak } & \multicolumn{4}{|c|}{ Porsentase Interval (Dalam \%) } & \multirow{2}{*}{ Tingkat Efektivitas } \\
\hline & & 2016 & 2017 & 2018 & 2019 & \\
\hline 1 & Pajak Reklame & 22,24 & 12,02 & 10.52 & 20.90 & Tidak Efektif \\
\hline 2 & Pajak Air Tanah & 16,13 & 2,78 & 7.97 & 11.90 & Tidak Efektif \\
\hline 3 & Pajak Sarang Burung Walet & 1,53 & 0,13 & 0.13 & 1.23 & Tidak Efektif \\
\hline 4 & $\begin{array}{c}\text { Pajak Mineral Bukan Logam dan } \\
\text { Batuan }\end{array}$ & 0,57 & 0,16 & 0.27 & 0.06 & Tidak Efektif \\
\hline
\end{tabular}

Dari realita angka tersebut dan informasi dari para informan ditemukan bahwa penetapan target pajak daerah terhadap Pajak Reklame, Air Bawah tanah , Sarang Burung Walet dan Pajak Mineral bukan logam dan Batuan belum ditetapkan berdasarkan data base perpajakan yang memadai sehingga capaian pada akhir tahun sangat jauh dari angka-angka target yang telah ditetapkan.

Rendahnya nilai realisasi dari 4 (empat) pajak daerah yang diteliti juga menunjukkan bahwa penetapan target yang over (terlalu tinggi) terhadap pajak-pajak tersebut semestinya sisa-sisa target yang tidak terealisasi harus dikompensasikan secara proporsional kepada 7 (tujuh) jenis pajak daerah lainnya yang dikelola oleh Pemerintah Kota Pekanbaru (Karena kota Pekanbaru mengelola 11 Jenis Pajak Daerah). Hal ini ditenggarai terkait motivasi penerimaan insentif bagi aparatur pengelola pajak daerah yang mana salah satu syaratnya adalah tercapainya target pajak dimaksud. Artinya ketiga angka-angka target tersebut dirasionalisasikan dengan cara mengkompensasikan ke jenis pajak lain (diluar pajak daerah yang diteliti) ditakutkan pajak lainnya tidak dapat terealisasi yang berimbas tidak dapat dibayarkannya insentif sebagai reward atas pencapaian kinera dimaksud.

"Nah terkait kenapa ada beberapa jenis pajak daerah yang capaian realisasinya sangat jauh dari nilai target yang telah ditetapkan, itu bisa saja ada kaitannya di internal OPD yang bersangkutan terkait penerimaan insentif sebagai bentuk reward atas jenis pajak yang tercapai. Karena kalau objek pajak tak memenuhi target, maka mereka tak akan menerima insentif". (IF1/PTPD/68).

Adanya masalah klasik yang belum dirampungkan yaitu Badan Pendapatan Daerah Kota Pekanbaru belum memiliki data yang cukup memadai sebagai bahan penghitungan Potensi Reklame, Air Bawah tanah, Sarang Burung Walet dan Pajak Mineral Bukan Logam batuan sehingga angka-angka itu selalu dibawa dari tahun ke tahun dalam penganggaran target pajak daerah. Sejauh ini perhitungan target terhadap 4 pajak daerah yang kami teliti didasarkan sebatas kepada estimasi tren target tahun sebelumnya.

“........memang 4 jenis pajak daerah yang pak Fauzan teliti tersebut merupakan 4 pajak realisasi terendah bila dibandingkan dengan pajak pajak lainnya. Sehingga pasti adanya kendala-kendala sehingga belum optimalnya penerimaan pajak daerah dari 4 jenis pajak daerah tersebut baik akibat tidak memadainya basis data, kendala SDM

Jati : Jurnal Akuntansi Terapan Indonesia, 2021 | 102 
yang ada didalamnya maupun sosialisasi sosialisasi kepada masyarakat sehingga perlu adanya upaya-upaya yang sekarang ini kurang potensial menjadi potensial..........". (IF4/KOPD/23).

Selanjutnya peraturan Internal Pemerintah Kota Pekanbaru atas pengelolaan Pajak Reklame, Air tanah, Sarang Burung Walet dan Pajak Minerba belum sepenuhnya memadai terutama dalam hal penetapan target Pajak Pajak tersebut yang seharusnya didasarkan kepada penghitungan potensi dengan dasar dan metodologi yang memadai untuk dapat dibuktikan.

“........Kalau jawaban jujur saya; sebetulnya kami disitu tahun 2018 sudah menerima angka target tersebut. Namun setahu saya (sejujurnya) Penetapan target itu seperti apa? Kalau menurut analisa saya memang kita belum maksimal dalam penyusunan target tersebut terlepas belum adanya panduan yang memadai." (IF2/ KOPDPTPD3/41).

Tidak tersedianya sumber daya manusia yang memadai dalam optimalisasi kegiatan pendataan ke lapangan yang lebih disebabkan oleh pengelolaan 4 pajak yang diteliti belum mendapatkan skala prioritas dari 11 jenis pajak daerah yang ada.

“....Karena satu bidang mengelola 9 Jenis Pajak daerah dengan keterbatasan SDM. Sehingga kita harus punya skala prioritas. Makanya kita lebih focus kepada pajak yang besar-besar." (IF2/ KOPD-KSDM/79).

Masih tidak memadainya politik lokal di kota Pekanbaru dalam artian keputusan penetapan target pajak daerah melalui penerbitan regulasi belum sepenuhnya berpihak kepada kepentingan optimalisasi pajak daerah itu sendiri.

"Nah itulah persoalan-persoalan pokok, Kenapa 4 pajak itu senantiasa berada di posisi terbawah. Kemudian juga ada permasalahan politik, politiknya apa? sebenarnya dari 4 potensi pajak itu memang ada potensinya namun tidak sebesar angka target yang telah ditetapkan itu potensinya. memang ada potensi pajaknya tapi sangat sedikit; seperti Minerba itu, kalau dulu namanya galian C, nah.. tetapi dibuat targetnya banyak. kan ada kepentingan politik namanya: Itu namanya politik anggaran....."(IF3/KOPD-PTPD/127).

Jumlah objek Pajak Mineral bukan logam dan batuan tidak signifikan dan pada umumnya objek pajak yang terdata dalam database Badan Pendapatan Daerah merupakan perusahaan/ badan usaha pemanfaat/Pemakai (bukan penghasil/pengambil) materialmaterial yang menjadi objek pajak mineral bukan logam dan batuan. Material mineral bukan logam dan batuan yang banyak beredar di kota Pekanbaru berasal dari daerah tetangga yang artinya bukanlah objek Pajak Mineral bukan logam dan batuan di Kota Pekanbaru melainkan objek pajak di tempat daerah asalnya.

“....Contoh kita bisa lihat di Pajak Mineral bukan Logam dan Batuan Pajak Minerba tersebut saya lupa berapa angka pastinya tetapi kalau kita lihat potensinya sebetulnya di Pekanbaru ini untuk Minerba tersebut kalau kita lihat Undang-Undangnya objeknya adalah pengambilan Minerba itu sendiri atau kegiatan pertambangan. Nah kita di Pekanbaru ini tidak ada Pertambangan minerba itu yang ada yang tergolong minerba tersebut hanya tanah timbun; kalau kerikil segala macam itu dari daerah lain sementara target kita disitu ada. Makanya saya anggap penetapan target itu belum 
pas kita menetapkan target sebanyak itu. Makanya kami lebih fokus kepada pajak 5 yang lainnya dibandingkan dengan yang 4 ini ". (IF2/ KOPD-PTPD4/44).

Selaras dengan informasi dari informan tersebut, penegasan juga terdapat dalam Pasal 57 Undang-Undang Nomor 28 tahun 2009 tentang Pajak Daerah dan Retribusi Daerah yang menyebutkan Objek Pajak Mineral Bukan Logam dan Batuan adalah kegiatan pengambilan Mineral Bukan Logam dan Batuan. Selanjutnya dikutip dalam buku pedoman Pajak dan Retribusi Daerah oleh Direktorat Pendapatan Daerah Dijen Bina Keuangan Daerah Kementerian Dalam Negeri RI juga menyebutkan bahwa Pemungutan Pajak Mineral Bukan Logam dan Batuan (MBLB) dilakukan pada kegiatan pengambilan bukan kegiatan pemanfaatan. Untuk mempermudah administrasi pemungutan, Pemda dapat memungut Pajak MBLB kepada kontraktor sepanjang MBLB tersebut berasal dari Daerah yang bersangkutan dan belum dikenakan Pajak MBLB.

Analisis Strategi dan Upaya Badan Pendapatan Daerah Kota Pekanbaru dalam Optimalisasi Kinerja Pajak Pajak Reklame, Pajak Sarang Burung Walet, Pajak Air Tanah, dan Pajak Mineral Bukan Logam dan Batuan

Carunia Mulya Firdausy dalam Optimalisasi Kebijakan Penerimaan Daerah (2017;50) menyebutkan pada prinsipnya optimalisasi pajak daerah dapat dicapai dengan memanfaatkan potensi-potensi yang ada melalui intensifikasi dan ekstensifikasi penerimaan pajak daerah. Intensifikasi dimaksud melalui perluasan basis penerimaan, memperkuat proses pemungutan, mengoptimalkan pengawasan, efisiensi administrasi dan meminimalisir biaya dan melakukan perencanaan perpajakan yang terintegrasi dengan melibatkan instansi terkait lainnya. Sementara pada ekstensifikasi dengan cara perluasan subjek, objek pajak dan pembaharuan tarif pajak.

Buku standarisasi pemungutan pajak daerah yang diterbitkan Kementerian dalam Negeri Republik Indonesia menyebutkan untuk melakukan pemungutan pajak daerah dan retribusi daerah membutuhkan komponen pendukung yaitu sarana dan prasarana yang memadai yaitu (1) Organisasi Sumber Daya Manusia; (2) Fasilitas Perkantoran; (3)Teknologi Informasi; (4) Data; dan (5) Standar Operasional Prosedur.

Hal-hal tersebut telah ditindaklanjuti oleh Badan Pendapatan Daerah Kota Pekanbaru sebagaimana yang tercantum dalam Laporan Akuntabilitas Kinerja Instansi Pemerintahan (LAKIP) dengan implikasinya terangkum dalam perbandingan pemanfaatan dana dengan capaian target kinerja pajak daerah dalam dua tahun terakhir :

Tabel 6. Perbandingan Nilai Dana Operasionalisasi dengan Nilai Realisasi Pajak Daerah di Bapenda Kota Pekanbaru (2018 - 2019)

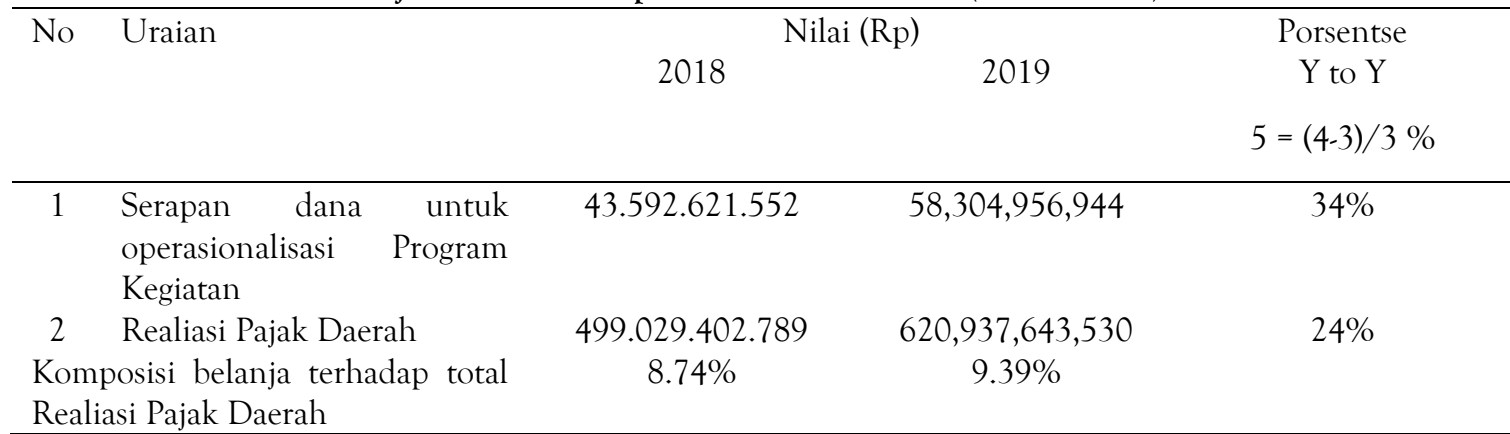

Sumber data: Bapenda Pekanbaru/diolah

Telah terjadi peningkatan dari sisi realisasi pajak daerah 24\% lebih tinggi atau 124\% dari tahun sebelumnya namun tingkat efektivitas dan efisiensi belum diperhitungkan oleh Bapenda karena terbukti persentase serapan dana operasionalisasi lebih tinggi dari 
persentase capaian target pajak $Y$ to $Y$ nya atau inefektif senilai 10\% (selisih persentase nomor 1 dan 2/ peningkatan serapan dana operasionalisasi tidak berbanding lurus dengan peningkatan capaian target kinerja).

Serapan dana APBD dalam tabel di atas adalah dalam rangka optimalisasi kinerja pajak reklame, sarang burung walet, air tanah dan mineral bukan logam dan batuan dalam bentuk:

1. Pendataan ulang dan upgrade database Pajak

Dari kegiatan pendataan ulang dan upgrade database sampai akhir tahun 2019, berikut merupakan jumlah Objek Pajak Reklame, Sarang Burung Walet, Air Tanah dan Mineral Bukan logam dan batuan di Kota Pekanbaru.

Tabel 7: Daftar Jumlah Objek Pajak yang Diteliti Per 31 Des 2019

\begin{tabular}{ccc}
\hline No & Nama Pajak & Jumlah \\
\hline 1 & Objek Pajak Reklame & 65.640 \\
2 & Objek Pajak Air Bawah Tanah & 1.074 \\
3 & Objek Pajak Mineral Bukan Batuan dan Logam & 1.061 \\
4 & Objek Pajak Sarang Burung Walet & 125 \\
\hline Sumber : Bapenda Kota Pekanbaru, diolah
\end{tabular}

Upaya optimalisasi penguatan database yang dilakukan dengan cara:

a. Melakukan pendataan langsung ke lapangan dan menginstruksikan Calon Wajib Pajak Sarang Burung Walet, Air Tanah dan Reklame untuk datang ke Kantor Badan Pendapatan Daerah Kota Pekanbaru dalam proses administrasi pendukungnya.

"Kami akan mendata, menginventarisir ke sudut-sudut kota Pekanbaru terhadap objek objek pajak Sarang Burung Walet dengan tidak memandang izin yang dimilikinya selama objeknya ada akan kami himbau untuk mendaftarkan diri ataupun kami daftarkan secara jabatan" (IF4/ SOPD- PDBP2/192).

b. Menerbitkan surat himbauan dan teguran kepada Pengusaha dan/ ataupun Wajib Pajak yang sudah terdaftar namun belum melakukan kewajiban pembayaran pajak Sarang Burung Walet, Reklame dan Air Bawah Tanah.

"...... dengan kegiatan semacam ini dilanjutkan dengan teguran-teguran, alhamdulilah banyak yang telah melaporkan dan membayarkan kewajiban perpajakan sarang burung waletnya ke kantor." (IF4/ SOPD- OPRM/118).

c. Optimalisasi Pemeriksaan oleh sub Bidang Pemeriksaan Pajak Daerah terhadap Subjek dan Objek Pajak Daerah yang membayar sendiri (Self Asesment) pada Pajak Sarang Burung Walet.

d. Melakukan kegiatan pendataan secara sembunyi-sembunyi terutama terhadap jenis pajak yang objeknya sangat sulit ditemui seperti Objek Pajak Sarang Burung Walet.

e. Melakukan Kegiatan Edukasi Kepatuhan Wajib Pajak Daerah sebagai upaya Optimalisasi penyampaian informasi kepada masyarakat dan sebagai sarana ekslusif dalam menggaet calon-calon Wajib Pajak baru.

f. Melakuan kegiatan cetak masal Surat Ketapan Pajak Daerah (SKPD) Reklame selama satu tahun.

2. Penguatan Kualitas dan Kuantitas Sumber Daya Manusia dalam pengelolaan Pajak Reklame, Air tanah dan Sarang Burung Walet dengan cara: 
a. Penguasaan teknik komunikasi melalui pelaksanaan In House Training (In House Training Aplikasi Single Windows, In House Training Pelayanan dan In House Training Teknik Komunikasi).

b. Pembentukan Satuan Petugas (Satgas) Pajak Daerah yang berfungsi sebagai garda terdepan dalam penertiban dan penyampaian Ketetapan pajak kepada Wajib Pajak dengan melibatkan Instansi terkait lainya dari aparatur penegak perda dan aparatur pengelola perizinan yang berhubungan dengan objek pajak tersebut.

c. Pengikutsertaan Aparatur Bapenda pada kegiatan Bimbingan teknis Perpajakan tingkat nasional seperti kegiatan pelatihan yang rutin dan berkelanjutan diselenggarakan oleh Kementerian Keuangan melalui Sekolah Tinggi Akuntansi Negara (STAN). Pelatihan dan diklat nasional yang telah diikuti oleh aparatur Badan Pendapatan Daerah Kota Pekanbaru di STAN adalah diklat Penilai PBB dan BPHTB, Diklat Pemeriksaan Pajak daerah dan Penagihan Pajak Daerah.

d. Pembekalan secara terus menerus dan berkelanjutan kepada Satuan Petugas yang dilakukan oleh Sub Bidang terkait yang rutin dilakukan setiap minggunya.

e. Ada rekruitmen khusus bagi calon pelaksana yang akan melaksanakan tugas sebagai Aparatur Sipil Negara (ASN) dilingkungan Badan Pendapatan Daerah Kota Pekanbaru karena Tingginya minat ASN yang ingin menjadi Pegawai Bapenda ditenggarai karena di instansi ini ASN berpeluang memperoleh insentif pajak daerah sebagaimana dimaksud dalam Peraturan pemerintah nomor 69 tahun 2010 tentang tata cara pemberian dan pemanfaatan insentif pemungutan pajak daerah dan retribusi daerah. Hal ini dimanfaatkan oleh OPD Bapenda dengan menjaring ASN yang berkualitas dan kompeten di bidang perpajakan daerah.

f. Membentuk Tim Pemeriksa Daerah yang didampingi oleh tenaga Fungsional Auditor Inspektorat Kota Pekanbaru melalui Keputusan Walikota Pekanbaru dengan melibatkan Aparatur Pengawas Internal Pemerintah (APIP) dalam hal ini adalah Fungsional Auditor dari Inspektorat Kota Pekanbaru. Sebelum kegiatan ini mandiri dilakukan oleh Pemerintah Kota Pekanbaru sudah disupervisi secara memadai oleh Fungsional Auditor Badan Pemeriksa Keuangan dan Pembangunan (BPKP) Kantor Perwakilan Provinsi Riau pada tahun 2015 dan 2016 silam.

3. Optimaliasi pemanfaatan teknologi informasi bagi layanan publik di bidang perpajakan daerah. Aspek utama yang ditekankan adalah pentingnya manajemen dan pengolahan data agar dapat membantu pengambilan keputusan otoritas pajak daerah. Mau tidak mau, berbagai limpahan data baik yang diperoleh internal maupun eksternal akan membanjiri database untuk selanjutnya bagaimana limpahan data tersebut dapat diolah menjadi sesuatu yang menghasilkan informasi yang bermanfaat untuk optimalisasi kinerja pajak daerah dengan cara:

a. Pengembangan Aplikasi Layanan Pajak dan Retribusi melalui Sistem Informasi dan Manajemen Objek Pajak yang sering disebut dengan istilah SISMIOP.

Sejauh ini Aplikasi ini terbatas mengakomodir administrasi Pajak Bumi dan Bangunan, mulai dari administrasi kantor, pendaftaran, penilaian, pemberian identitas Nomor Objek Pajak, pemrosesan, pemeliharaan, sampai dengan keluaran cetak yang berupa Surat Pemberitahuan Pajak Terhutang. Kedepannya aplikasi ini akan dikembangkan untuk optimalisasi pengolahan data Pajak Reklame, Air tanah dan sarang burung walet. Spesifikasi design Aplikasi SISMIOP ini adalah Berbasis Web, Menggunakan API Maps Google; untuk memetakan area/tanah; diibangun dengan framework Codelgniter, Database menggunakan MySQL dan desain antar muka responsif. Output dari aplikasi ini adalah Pendaftaran Objek dan Subjek Pajak; Pendataan Objek dan Subjek Pajak; Penelitian; Pemberian Identitas Objek Pajak 
(NOP); Perekaman Data; Pemeliharaan Basis Data; Pencetakan Hasil Keluaran; Pemantauan Penerimaan/Pembayaran dan Pelayanan Satu Tempat.

b. Mengubah pola aplikasi Pajak yang terpisah (SISMIOP \& SISDURPATDA) menjadi satu frame work Single Windows (satu aplikasi dalam satu jendela kerja).

Aplikasi layanan SISMIOP dan SISDURPATDA adalah dua aplikasi berbeda. SISMIOP ditujukan untuk pengelolaan paajak PBB dan BPHTB sementara SISDURPATDA merupakan pengelolaan pajak daerah non PPB dan BPHPB. Sebelumnya dua aplikasi ini berdiri sendiri dan tidak saling terintegrasi. Host to host atau sering dikenal $\mathrm{H} 2 \mathrm{H}$ memiliki pengertian "sistem antar server yang terhubung satu sama lain secara langsung". Lebih sederhananya: "komunikasi dan/ ataupun hubungan dalam satu jaringan komputer yang terjadi antar host, yaitu komputer dengan perangkat lain yang saling terhubung satu sama lain".

Fungsinya, sistem ini menyatukan beberapa aplikasi berbeda dalam satu layanan selain itu juga berfungsi untuk pembayaran dimana Wajib Pajak dapat langsung membayar pajak secara elektronik via ATM atau channel pembayaran lainnya yang telah bekerja sama dengan Badan Pendapatan Daerah Kota Pekanbaru. Dengan adanya program server Host to Host ini membuat Wajib Pajak menjadi lebih mudah dalam proses administrasi perpajakannya. Pembayaran Online Pajak Daerah secara Host-to-host $\left(\mathrm{H}_{2} \mathrm{H}\right)$ juga telah bekerjasama dengan pihak Perbankan (Bank Riau-Kepri,Bank BNI dan Bank BJB) serta gerai-gerai pembayaran lainnya seperti Go Jek, Alfa Mart, Indomaret, dan tempat strategis lainnya tanpa dana APBD. H2H lainnya juga ada melalui e-Channel yang telah dilaunching Bapenda Kota pekanbaru pada tanggal 28 Oktober 2019 yang lalu dimana Bapenda Kota Pekanbaru juga telah bekerjasama dengan empat aplikasi e-commerce terkemuka yaitu Traveloka, Bukalapak, Tokopedia, dan LinkAja.

c. Kerjasama dengan pihak vendor dalam hal ini adalah PT. Bank Riau Kepri dalam pemanfaatan perangkat TMD (Transaction Monitoring Device).

Dengan alat ini dimungkinkan Badan Pendapatan Daerah Kota Pekanbaru untuk memonitor transaksi wajib melalui pemasangan alat taping box yang ditaruh pada peralatan/ media elektronik wajib pajak. Sehingganya seluruh transaksi akan terdeteksi di kantor Bapenda dan akan digunakan sebagai alat verifikasi oleh pihak Bapenda ketika Wajib Pajak akan melakukan pelaporan Surat Pemberitahuan Pajak Daerah (SPTD).

Hal ini juga telah diakomodir dalam peraturan pelaksanaan pada level Peraturan Walikota yang mengatur tatacara pelaksanaan pemungutan pajak daerah per jenis pajak daerah. Kegiatan ini cukup terbukti efektif meningkatkan optimalisasi pajak daerah yang telah dipasangi taping box (alat perekam data transaksi Wajib Pajak).

d. Bekerjasama dengan Dinas Kependudukan dan Catatan Sipil Kota Pekanbaru

Dalam optimalisasi pemanfaatan catatan kependudukan dalam optimalisasi pendataan Wajib Pajak Daerah yang terintegrasi dengan Sistem Kependudukan Adminduk Kementerian Dalam Negeri regional kota Pekanbaru. Dalam rangka terintegrasinya potensi perpajakan di kota Pekanbaru, Bapenda juga telah menjalin kerjasama dengan Disdukcapil Kota Pekanbaru dengan memanfaatakan Identitas kependudukan yang tercatat di sistem Adminduk Kemendagri regional Pekanbaru. Sehingga kedepan akan tersandingkan data penduduk yang telah menjadi Wajib Pajak Daerah di Kota Pekanbaru. Hal ini akan mempermudah melacak keberadaan Wajib Pajak sehingga kedepan penyampaian informasi dalam bentuk surat akan

Jati : Jurnal Akuntansi Terapan Indonesia, 2021 | 107 
lebih mudah dan dapat terpetakan potensi masing-masing pajak daerah per wilayah kerja di Kota pekanbaru.

e. Penyampaian iklan yang masif di media media sosial Badan Pendapatan Daerah Kota Pekanbaru melalui Facebook, Instragram, Youtube dan Website Badan Pendapatan Daerah Kota Pekanbaru.

4. Optimalisasi penguatan sarana dan prasarana pendukung optimalisasi Pajak Reklame, Air Tanah dan Sarang Burung Walet.

a. Pelayanan yang cepat, tepat dan terencana dengan hasil yang diharapkan adalah percepatan dari hasil yang direncanakan. Badan Pendapatan Daerah Kota Pekanbaru telah melaksanakan berbagai strategi dengan target pelayanan yang sebanyak- banyaknya dan secepat-cepatnya, target lain dari pelayanan adalah koordinasi dan kolaborasi kerja antar bidang yang sesuai data dan fakta sehingga semua bentuk pajak yang akan dibayarkan dapat diberikan pelayanan maksimal, sampai saat ini rata-rata pelayanan mencapai 200 orang masyarakat setiap harinya, hal ini diharapkan dapat meningkat sesuai sarana, prasarana dan kompetensi pegawai yang dimiliki selain penerapan disiplin dan kebijakan pimpinan. Hal ini sudah diatur sedemikian rupa dalam Standar Operasional Prosedur Pelayanan di Badan Pendapatan Daerah Kota Pekanbaru.

b. Penguatan Sarana dan Prasarana yang dimiliki Bapenda Kota Pekanbaru seperti Gedung Kantor yang terpadu dengan design dinamis terdiri dari : Ruang Tunggu, Loket Informasi, Loket pelayanan terdiri dari 13 Loket yang menangani berbagai pajak daerah, Bank Daerah dan Bank BUMN, penyediaan sarana pendukung dengan stake holder terkait dimana pembayaran pajak daerah telah dapat dilakukan di pusat perbelanjaan harian dan tempat tempat strategis lainnya.

c. Dukungan pendanaan operasionalisasi melalui Perencanaan dan penganggaran kegiatan dalam Anggaran Pendapatan dan Belanja Daerah (APBD)

Guna memenuhi pencapaian target terhadap capaian kinerja yang dihasilkan oleh Badan Pendapatan Daerah Kota Pekanbaru, Sekretariat dalam perannya sebagai koordinator fungsi di bidang pengelolaan (manajemen) kepegawaian, program dan sapras pendukung, telah melaksanakan berbagai program dalam satu tahun anggaran (annual budget). Maksud dan tujuan program tersebut adalah dalam rangka terpeliharanya aset tetap bergerak maupun tidak bergerak yang menjadi naungan Badan Pendapatan Daerah Kota Pekanbaru dan terlaksananya semua kegiatan yang terkait dalam Program Optimaliasi Pajak daerah di Kota Pekanbaru. Terdapat 8 (Delapan) Program dan 36 (Tiga Puluh Enam) Kegiatan yang merupakan penjabaran dari Rencana Strategis dalam Dokumen Pedoman Anggaran Badan Pendapatan Kota Pekanbaru Mewujudkan infrastruktur pendukung lainnya yang memadai untuk optimalisasi kinerja pajak daerah yaitu:

1) Tersedianya ruangan khusus yang representatif dan memadai sebagai ruangan verifikasi dan ruangan konsultasi bagi Wajib Pajak.

2) Membuat logo kantor yang menarik dan mencolok sebagai identitas kantor Bapenda

3) Membenahi dan merombak model mobil operasional sehingga mobil operasional Bapenda memiliki ciri khas tersendiri dari mobil operasioal perangkat daerah lainnya.

5. Untuk Pajak Mineral Bukan Logam dan Batuan tidak ada usaha optimalisasi yang memadai dimana hanya memanfaatkan kegiatan pemotongan melalui pencairan dana 
oleh Bendahara Umum Daerah terhadap usahawan konstruksi pengguna material mineral bukan logam dan batuan.

Faktualnya objek pajak Mineral bukan logam dan batuan di Kota Pekanbaru tidaklah signifikan, jumlah yang terdaftar rata-rata bukanlah sebagai penghasil galian $\mathrm{C}$ dimaksud lebih kepada pemanfaat. Berdasarkan pertimbangan dalam konsideran Undang-Undang Nomor 28 tahun 2009 tentang Pajak Daerah dan Retribusi Daerah disebutkan bahwa bahwa kebijakan pajak daerah dan retribusi daerah dilaksanakan berdasarkan prinsip demokrasi, pemerataan dan keadilan, peran serta masyarakat, dan akuntabilitas dengan memperhatikan potensi daerah yang dipertegas dalam Pasal 2 yang pada prinsipnya menyebutkan bahwa jenis pajak dapat tidak dipungut apabila potensinya kurang memadai dan/atau disesuaikan dengan kebijakan Daerah yang ditetapkan dengan Peraturan Daerah.

Artinya penetapan pajak daerah yang menjadi kewenangan Pemerintah Daerah menetapkannya harus tetap ditumpukan pada prinsip cost benefit analysis yaitu proses pembandingan biaya yang diperkirakan dengan manfaat yang berkaitan erat dengan pembuatan keputusan, untuk menentukan apakah keputusan yang akan dibuat tersebut masuk akan atau tidak dari berbagai perspektif.

Yang dimaksud dengan biaya adalah kelemahan-kelemahan yang mungkin akan muncul dari keputusan tersebut, sementara manfaat atau keuntungan yang dapat diperoleh. Secara sederhana, cost benefit analysis dapat diartikan sebagai proses menghitung semua biaya dari sebuah sebuah keputusan. Apabila melalui analisis tersebut ditemukan bahwa manfaat (benefit) lebih besar dari biaya (cost), maka bisa dianggap bahwa keputusan tersebut sudah tepat. Sebaliknya, jika biaya lebih besar dari manfaat, maka pengambilan keputusan tersebut harus dipikirkan kembali.

Analisis Faktor-faktor kendala dalam optimalisasi kinerja Pajak Reklame, Pajak Sarang Burung Walet, Pajak Air Tanah, dan Pajak Mineral Bukan Batuan dan Logam

\section{Pajak Sarang Burung Walet}

a. Peraturan Internal Pemerintah Kota Pekanbaru atas pengelolaan Pajak Sarang Burung Walet belum sepenuhnya memadai.

Regulasi pelaksanaan yang diterbitkan sejauh ini terkesan hanya copy paste dari aturan di atasnya artinya tidak ada turunan aturan yang rinci dan memadai terutama menghilangkan akibat ambigu bahasa peraturan perundangan yang ada di atasnya. Selanjutnya regulasi yang saling bertabrakan di Kota Pekanbaru yang mana ada 2 (dua) regulasi berbeda sekaitan operasionalisasi sarang burung wallet ini yaitu regulasi perizinan dan regulasi pajak sarang burung wallet sendiri. Aturan dimaksud adalah Peraturan Daerah Kota Pekanbaru Nomor 3 tahun 2007 tentang Izin Usaha Pengelolaan dan pengusahaan Sarang Burung Walet Pasal 6 menyebutkan bahwa untuk penangkaran sarang burung walet dengan jarak sekurang-kurangnya 100 (seratus) meter dari pemukiman penduduk dan menyebutkan fungsi bangunan untuk wallet ini dengan pernyataan tidak keberatan dari tetangga kiri, kanan, muka dan belakang yang ikut diketahui oleh Lurah dan camat setempat. Aturan lainnya ada pada Peraturan Daerah Kota Pekanbaru Nomor 10 tahun 2011 tentang Pajak Sarang Burung Walet, aturan ini terbit akibat ditetapkannya Undang-Undang Nomor 28 tahun 2009 tentang Pajak Daerah dan Retribusi Daerah. Informasi pertentangan ini diungkapkan oleh salah satu informan dari Bapenda Kota Pekanbaru yang menyebutkan bahwa fenomena di lapangan banyak usaha wallet yang tetap beroperasi di tengah pemukiman masyarakat, yang menurutnya seharusnya ada sinkronisasi antara perizinan dengan pajak yang dipungut namun pihak Bapenda tetap melakukan pemungutan mesti izinnya tidak ada karena yang menjadi patokan 
Bapenda adalah nilai ekonomis dan objeknya, menurut pengakuannya Pemko Pekanbaru bisa rugi dua kali sudah tidak punya izin dan juga tidak bayar pajak makanya pihak Bapenda tetap memungut pajaknya. Sehingga pendataaan ke lapangan terkait objek objek pajak ini dan memerintahkan para usahawan datang ke kantor untuk diteliti lebih lanjut untuk melakukan pembayaran pajak sarang burung wallet ini. Selanjutnya kurangnya realisasi penerimaan pajak sarang burung wallet juga diduga kuat terjadi karena rendahnya tarif yang ditetapkan untuk Pajak Sarang Burung Walet dalam regulasi pajak daerah tentang Pajak Sarang Burung wallet

Pada prinsipnya persoalan ini harus diatasi karena apapun pilihan yang diambil Pemerintah termasuk memungut pajak sekalipun terhadap objek yang tak ada izinnya akan dianggap oleh pemilik usaha sebagai bentuk pengakuan pemerintah (legalitas) terhadap usahanya sementara usahanya jelas-jelas melanggar aturan semisalnya ditengah pemukiman padat penduduk dan lainnya. Setidaknya aturan ini harus menjadi satu kesatuan yang utuh tanpa harus terpecah ke dalam dua aturan berbeda. Mengingat kekhasan usaha ini harus betul betul dikaji agar tidak melalaikan efek lingkungkan yang ada. Penguatan ini tersirat dari salah seorang informan yang menyebutkan bahwa mengapa ilmu pemerintahan dapat dijadikan landasan teoritis dari penelitian ini tadi disebutkan bahwasanya ilmu pemerintahan menjelaskan bagaimana institusi-institusi pemerintahan melaksanakan fungsi-fungsinya yang tujuan akhirnya adalah adalah kesejahteraan masyarakat bukan hanya semata-mata peningkatan Pendapatan asli daerah semata (PAD). Selanjutnya dalam Undang Undang Nomor 23 tahun 2014 dipertegas juga bahwa Pemerintah harus menjalankan pemerintahannya harus sesuai peraturan perundang-undangan.

b. Kekhasan bisnis sarang burung walet menjadi kendala dalam pendataan oleh Pihak Bapenda Kota Pekanbaru

Bisnis sarang burung walet sarat resiko dan butuh penanganan khas dalam penakaran sarangnya. Habitat burung walet aslinya ada di wilayah pantai atau menghuni gua-gua, serta ruang besar lainnya. Burung ini biasanya hidup berkelompok dan membentuk sarang dari air liur mereka yang mengeras. Sarang burung walet inilah yang dibisniskan untuk dikonsumsi, kesehatan, kecantikan, dan manfaat lainnya. Sehingga untuk ditakarkan secara non alami membutuhkan investasi besar dalam mempersiapkan bangunannya yang harus steril dari segala macam hama dan gangguan. Dan masih banyak lagi kekhasan dari bisnis ini yang menimbulkan tantangan tersendiri dalam pendataan objek dan subjek pajak ini.

Berdasarkan informasi yang kami rangkum dari para informan menyebutkan bahwa kurangnya realisasi penerimaan pajak sarang burung walet disebabkan oleh pendataan yang kurang memadai disebabkan oleh:

1) Dalam melakukan pendataan oleh petugas, wajib pajak sarang burung walet tidak pernah ditempat sehingga sulit ditemui karena rata-rata pemilik usaha ini adalah pemain besar dari luar daerah dan mereka menjadi salah satu "musuh besar" dari pengusaha sarang walet lokal yang belum mapan artinya antara subjek dan objek pajak tidak pernah sama.

2) Halangan lain adalah dengan maraknya terjadi pencurian sarang walet. Sehingga banyak pengakuan dari wajib pajak ketika pelaporan ke Bapenda bahwa sarang burung walet mereka telah dicuri sehingga tidak ada transaksi yang dilaporkan yang artinya menihilkan pembayaran kewajiban pajak sarang burung waletnya.

3) Pendataan yang kurang memadai karena tidak diketahuinya secara pasti kapan masa panen walet dimaksud. 
4) Pendataan yang kurang memadai juga disebabkan oleh berkurangnya jumlah pengusaha sarang burung walet akibat tidak stabilnya harga sarang burung walet di pasaran.

5) Pendataan yang kurang memadai karena adanya regulasi yang mengatur letak tempat usaha walet harus/minimal 100 meter dari pemukiman warga.

\section{Pajak Reklame}

a. Kegiatan Pendaftaran Wajib Pajak Reklame belum memadai

Belum adanya upaya terstruktur dan sistemik pendataan objek pajak dan Wajib Pajak Reklame sebagai perhitungan potensi Pajak Reklame secara riil. Sejauh ini kegiatan turun lapangan oleh para satgas terkesan tugas rutinitas tanpa evaluasi secara berkala dan memadai. Hal ini juga disebabkan tidak ada acuan yang memadai kepada petugas di lapangan oleh pejabat terkait. Output kegiatannya juga tidak dipertajam sehingga satgas lapangan lebih kepada penertiban reklame illegal semata, belum ada upaya untuk memperbaiki database pajak reklame yang seharusnya sudah harus digesa pelaksanaanya.

Setidaknya melalui petugas yang turun ke lapangan harus merangkum datadata potensi riil dengan mempertimbangkan jenis reklame, bahan reklame yang digunakan, ukuran reklame, dimensi reklame, jumlah reklame dan posisi reklame (apakah ditempat strategis/ bukan). Data reklame tersebut akan dapat diinventarisir lebih lanjut dan sebagai bahan perbandingan dengan database yang ada dalam sistem aplikasi reklame. Dengan kegiatan rutin serupa dan komitmen yang berkelanjutan diharapkan akan ada semacam peta, sehingga semua reklame yang berada di ruas jalan tersebut tercatat dengan baik dan memadai.

b. Kegiatan Penatausahaan Penagihan Pajak Reklame belum Memadai

Disebabkan keterbatasan sumber daya manusia, sehingga prioritas kepada Pajak Reklame juga tidak seperti yang dilakukan kepada jenis pajak daerah lainnya (di luar 4 jenis pajak daerah yang sedang diteliti). Berdasarkan catatan lapangan yang kami miliki tidak ada usaha yang signifikan malah boleh dikatakan Bidang Penagihan tidak melakukan tugasnya sesuai dengan tupoksinya terkait dengan tunggakan Pajak Reklame Wajib Pajak yang telah berakhir jatuh tempo pembayaran sehingga mengakibatkan banyaknya Wajib Pajak Reklame yang menunggak membayar pajak namun tidak tercatat dalam daftar tunggakan pajak reklame sehingga belum ada efek jera bagi Wajib Pajak yang tidak menindaklanjuti kewajiban perpajakannya. Sejauh ini Badan Pendapatan Daerah kota Pekanbaru masih menyicil kegiatan penagihan dan ataupun pemutakhiran terhadap tagihan Objek Pajak PBB dan BPHTB akibat adanya angka tagihan/ piutang pajak daerah bawaan saat serah terima pajak tersebut yang sebelumnya dikelola langsung oleh Direktorat Jenderal Pajak Kementerian Keuangan Republik Indonesia dan hal serupa hampir terjadi disetiap Kabupaten/Kota.

c. Pengelolaan Pajak Reklame belum didukung dengan Struktur Organisasi Yang Memadai

Pajak Reklame adalah jenis pajak daerah yang dibayarkan oleh Wajib Pajak berdasarkan ketetapan (Official Asesment). Melihat potensi besar pajak reklame di kota Pekanbaru seyogyanya pengelolaannya disamakan dengan pengelolaan Pajak Bumi dan Bangunan sektor Perkotaan dan Pedesaan (PBB-P2). Dalam pengelolaan PBB-P2 urutan tahapan dan eksekusi kegiatan terstruktur secara memadai misalnya dalam penyebaran SPPT PBB melibatkan seluruh stakeholder seperti Camat, Lurah 
sampai RW dan RT. Sehingga penyebaran tagihan PBB lebih optimal dibandingkan dengan pajak reklame.

Selanjutnya banyaknya jumlah pajak daerah yang dikelola oleh Bidang Pajak Daerah II yang mengelola 8 jenis pajak dibandingkan bidang pajak daerah I yang hanya mengelola 3 jenis pajak daerah yang membuat bidang pengelola pajak hotel, restoran, hiburan, parkir, air tanah, reklame dan mineral bukan logam dan batuan ini agak ketimpangan dibandingkan bidang Pajak Daerah I. Seyogyanya perlu dipertimbangkan penataan ulang kembali struktur organisasi agar tingkat beban kerja disesuaikan dengan kemampuan masing-masing lini aparatur dimaksud sehingga dapat dicapai tingkat optimalisasi kinerja sebagaimana diharapkan organisasi Badan Pendapatan Daerah ini.

d. Belum Optimalnya Koordinasi antar instansi instansi terkait.

Tidak terinventarisirnya data base pajak reklame di Kota Pekanbaru membuktikan tidak sinkronnya data yang ada di Instansi Perizinan dalam hal ini di DPMPTSP dengan Badan Pendapatan Daerah. Seharusnya data yang ada pada dua Organisasi Perangkat Daerah (OPD) ini dapat saling bersinergi untuk optimalisasi database reklame itu sendiri. Hal ini telah dipertegas dalam Peraturan Daerah Kota pekanbaru Nomor 04 tahun 2011 yang terakhir telah dirubah dengan Peraturan Daerah Nomor 4 tahun 2018 tentang Pajak Reklame yang menyebutkan bahwa setiap penyelenggaraan reklame dalam Wilayah Kota Pekanbaru wajib memiliki izin dari Walikota atau pejabat yang ditunjuk selanjutnya sebelum izin diterbitkan harus membayarkan pajak reklame ke Badan Pendapatan Daerah. Artinya data terkait reklame antara OPD dimaksud harus sama karena prosesnya saling terkait. Dengan optimalisasi koordinasi ini akan dapat diciptakan database pajak reklame yang memadai karena unsur pengawasan dari sisi perizinan dan perpajakannya dimiliki oleh kedua instansi ini. Apabila konsistensi ini dapat dijaga tentu optimalisasi kinerja pajak reklame akan dapat ditingkatkan lagi. Akibat dari kurangnya koordinasi antara Instansi terkait seperti dikemukakan di atas maka tidak diperoleh informasi yang akurat tentang berapa jumlah pengusaha reklame yang telah memiliki ijin usaha dan berapa yang belum memiliki ijin usaha yang pada akhirnya menghambat optimlisasi pajak reklame tersebut.

Sejauh ini koordinisasi yang sudah dilaksanakan adalah sebatas operasi bersama antara Badan Pendapatan Daerah bersama aparatur perizinan dari Dinas Penanaman Modal dan Pelayanan Terpadu Satu Pintu dan Satuan Polisi Pamong Praja dalam tinjauan lokasi ke beberapa titik reklame di Kota Pekanbaru. Kedepan hal teknis lainnya harus dioptimalksan misalnya adanya kegiatan rekonsiliasi data secara berkala dan berkelanjutan begitupun dengan pengawasannya sehingga data-data potensi pajak reklame tetap terjaga dan terverifikasi. Sejauh ini belum ada rekonisiliasi dimaksud baik yang dilakukan secara manual ataupun saling terintegrasinya system data base di antara dua OPD terkait ini.

e. Belum optimal dan tepat gunanya pemanfaatan teknologi informasi dalam optimalisasi kinerja pajak reklame.

Pemanfaatan teknologi informasi dalam optimalisasi pajak reklame boleh dikatakan sangat terbatas, sejauh ini hanya ada layanan IT untuk penghitungan pajak reklame dan penerbitan Surat Ketetapan Pajak Daerah (SKPD) Reklame. Berdasarkan pengakuan dari salah satu wajib pajak menyatakan bahwa mereka harus membawa seluruh reklame insidentil (reklame berupa umbul-umbul dan sejenisnya) ke Kantor Bapenda Kota pekanbaru untuk dicap dan divalidasi untuk selanjutnya setelah memenuhi kewajiban pajaknya baru dapat dipasang ditempat-tempat yang telah 
ditentukan. Tentu ini sangat inefektif dan sangat memberatkan wajib pajak. Bisa dibayangkan seandainya ada ratusan lembaran reklame yang akan dipasang dan semuanya harus dicap dulu ke Bapenda lalu didistribusikan lagi ke tempat-tempat pemasangan. Mestinya harus ada terobosan pemanfaatan logo elektronik (hologram) misalnya yang sudah dikaji secara matang dan terukur sehingga Wajib Pajak hanya membawa sampel. Tentu kebijakan ini harus dibarengi dengan pengawasan yang ketat oleh Badan Pendapatan Daerah Kota Pekanbaru.

Selanjutnya pengakuan terkait terbatasnya Sumber Daya Manusia dalam pengelolaan pajak reklame menunjukkan belum efektifnya pemanfaatan teknologi informasi untuk optimalisasi kinerja pajak reklame ini. Salah satu ciri dari adanya pemanfaatan teknologi informasi adalah berkurangnya peranan tenaga manusia dalam pencapaian tujuan suatu organisasi. Kedepannya Badan Pendapatan Daerah harus mangajukan usulan kepada developer sistem aplikasi untuk memperbaiki kelemahan-kelemahan yang ada untuk pengembangan sistem yang memadai sehingga kegiatan pajak reklame mulai dari penetapan sampai penagihan termonitor dalam layar saja, sehingga pekerjaan manualnya hanya ada pada tingkat pengawasan di lapangan.

\section{Pajak Air Bawah Tanah}

a. Terbatasnya jumlah Sumber Daya Manusia yang memadai untuk optimalisasi Air Bawah Tanah

Mengingat skala prioritas pemungutan pajak sebagaimana yang disinggung sebelumnya lebih diarahkan kepada jenis pajak daerah lainnya (diluar 4 jenis pajak yang sedang diteliti) mengakibatkan kurang keberpihakan kepada SDM Pengelola pajak air tanah ini. Berdasarkan hasil wawancara ditemukan faktual bahwa kegiatan pendataan pernah dilakukan pada tahun 2018 dengan memverifikasi Wajib Pajak Wajib Pajak besar seperti hotel dan objek signifikan lainnya. Dari data verifikasi tersebut lalu dieksekusi dalam Surat Ketetapan Pajak Daerah (SKPD) air tanah yang diterbitkan. Usaha ini membuahkan hasil dengan naiknya realisasi kinerja pajak air tanah dari tahun tahun sebelumnya. Namun sayangnya data tersebut terus dipakai dalam penetapan SKPD SKPD air tanah selanjutnya sehingga data potensi tidak ter up date lagi. Alasan keterbatasan kuantitas Sumber Daya Manusialah yang menyebabkan kegiatan ini tidak dapat dilaksanakan secara masksimal lagi.

b. Belum adanya sarana pendukung yang memadai dalam optimalisasi pajak Air Bawah Tanah misalnya tidak ada Mesin Pengukur di masing-masing objek pajak sehingga volume pamanfaatan air tidak diketahui secara akurat dan hanya mengandalkan sarana prasarana milik Wajib Pajak dalam penghitungan volume.

Sampai saat ini Badan Pendapatan Daerah Kota Pekanbaru belum memiliki alat pengukur yang dapat menjadi dasar penghitungan pemakaian air oleh Wajib Pajak. Sejauh ini Badan Pendapatan Daerah masih mengandalkan data survei beberapa tahun yang lalu dan bagi wajib pajak seperti usahawan hotel dan sejenisnya yang memiliki mesin pengukur, Bapenda dapat agak bernafas lega menggunakan angka-angka tersebut sebagai dasar penerbitan SKPDnya. Kedepannya Bapenda harus memiliki kajian yang memadai tentang pengadaan mesin pengukur ini dengan mempertimbangkan prinsip cost and benefit, apakah memadai dengan pengadaan infrastruktur dimaksud bila dibandingkan dengan hasil pajak yang akan diterima setiap bulannya.

c. Belum optimalnya sosialisasi tentang Pajak Air Bawah Tanah kepada masyarakat pemanfaat air bawah tanah untuk keperluan komersil. 
Berdasarkan hasil wawancara dengan salah seorang informan yang merupakan Wajib Pajak Air tanah, peneliti memperoleh keterangan bahwa mereka belum mengetahui informasi secara memadai terkait tatacara penghitungan pajak air tanah ini, sejauh ini mereka hanya membayar sebesar SKPD yang telah diterbitkan. Dengan tetap mengedepankan prinsip prinsip pemungutan official assessment yang artinya kewenangan penetapan pajak daerah oleh pihak Badan pendapatan Daerah namun mereka sangat berharap akan adanya sosialisasi yang memadai kepada para wajib pajak sehingga para wajib pajak dapat membuat estimasi estimasi biaya untuk kebutuhan bisnis mereka kedepan.

Selanjutnya wajib pajak tersebut juga berharap kepada Pemerintah Kota Pekanbaru perlu mensuport mereka melalui regulasi yang lebih mengedapankan azas keadilan misalnya dalam penetapan standar harga berdasarkan klasifikasi bintang untuk hotel (agar tidak terjadi kesenjangan dalam penjualan produk) dan selanjutnya juga agar Pemda mengadakan acara-acara berskala nasional maupun internasional bekerja sama dengan usahawan lokal di kota Pekanbaru untuk meningkatkan pendapatan daerah sehingga akan berdampak juga pada pendaptan yang juga merupakan objek pajak daerah, dengan meningkatnya pendapatan tersebut tentu pengusaha dan/ataupun wajib pajak tidak akan merasa berat dalam membayar pajak daerah.

\section{Pajak Mineral Bukan Logam dan Batuan}

Tidak realistisnya target yang ditetapkan terhadap Pajak Mineral bukan Logam dan Batuan dan mengingat tidak signifikannya objek pajak ini di Kota Pekanbaru, seharusnya Pajak Minerba tidak perlu dijadikan sebagai salah satu objek yang harus diperdakan di Kota Pekanbaru. Menelisik ke kota besar lainnya (informasi diperoleh ketika peneliti mengikuti webinar secera live streaming di Youtube yang ditaja DDTC News), di Kota Medan jenis pajak ini juga tidak dipungut karena tidak signifikannya objeknya di Ibu kota Provinsi Sumatera Utara tersebut.

Bahwa untuk saat ini objek Pajak Mineral bukan Logam dan Batuan idealnya tidak ditetapkan sebagai salah satu sumber pajak daerah di Kota Pekanbaru. Hal ini juga sesuai dengan pendapat Dye (1978: 3) tentang kebijakan publik yang dijadikan sebagai salah satu landasan teori dalam penelitian ini yang mengatakan "Policy is whatever governments choose to do or not to do".

\section{KESIMPULAN}

Penetapan target Pajak Reklame, Sarang Burung Walet, Air Tanah dan Mineral Bukan Logam dan Batuan di Kota Pekanbaru belum disesuaikan dengan potensi ril pajak daerah tersebut. Penentuan target pajak tersebut tidak didukung oleh Peraturan Internal Pemerintah Kota Pekanbaru dalam menentukan rumusan metodologi yang memadai sehingga ditemukannya over target terhadap 4 (empat) pajak daerah. Nilai over target tersebut semestinya dikompensasikan kepada 7 (tujuh) jenis pajak lainnya yang yang dikelola oleh Pemerintah Kota Pekanbaru. Selain itu ditemukan fakta bahwa tidak signifikannya Subjek dan Objek Pajak Mineral bukan Logam dan Batuan di Kota Pekanbaru sehingga tidak perlu di targetkan sebagai pendapatan pajak daerah di Kota Pekanbaru.

Strategi dan upaya yang telah dilakukan terhadap optimalisasi 4 (empat) jenis pajak tersebut belum sepenuhnya memadai sehingga menyulitkan pengambilan keputusan yang cepat, tepat dan terintegrasi. Upaya yang telah dilakukan dalam upgrade database, penguatan sumber daya manusia, optimalisasi pemanfaatan teknologi informasi dan sarana 
prasarana pendukung lebih dititik beratkan kepada 7 jenis pajak daerah lainnya yang merupakan objek pajak daerah lainnya yang bukan objek penelitian.

Faktor-faktor kendala dalam optimalisasinya adalah belum tersedianya Struktur Organisasi dan Tata Kerja yang memadai dalam optimalisasi Pajak Reklame, belum dimutakhirkannya data base Perpajakan Pajak Reklame, Air Tanah, Sarang Burung Walet dan MBLB, kondisi Sumber Daya Manusia yang belum memadai dari sisi kuantitas maupun kualitas, terbatasnya optimalisasi pemanfaatan teknologi informasi yang tepat guna, terbatasnya Optimalisasi Penguatan Regulasi pendukung dan terbatasnya sarana dan prasarana pendukung.

Penelitian ini memiliki keterbatasan adalah terkait objek yang diteliti yaitu terhadap 4 jenis pajak daerah dengan realisasi terendah di Kota Pekanbaru. Guna Optimalisasi Pendapatan Asli Daerah (PAD) dari sektor Pajak Daerah di Kota Pekanbaru perlu dilakukan kajian menyeluruh terhadap seluruh objek pajak daerah sehingga nilai over target pajak reklame, air tanah, sarang burung wallet dan mineral bukan logam dan batuan dapat dikompensasikan secara proporsional kepada 7 jenis pajak daerah lainnya dalam dokumen Anggaran Pendapatan dan Belanja Daerah (APBD).

Penelitian ini memiliki implikasi praktis pada pemerintah kota Pekanbaru dalam merumuskan kebijakan dalam Penguatan Peraturan Internal Pemerintah untuk optimalisasi pengelolaan Pajak Reklame, Air tanah dan Sarang Burung Walet. Pembuatan laporan strategi dan upaya yang memadai (terukur dan terintegrasi) per Jenis Pajak Daerah dengan mempertimbangkan indikator-indikator terkait sehingga dapat dimanfaatkan dalam dokumen perencanaan dan evaluasi kinerja terhadap masing-masing objek pajak daerah.

Penelitian ini juga memperkaya kajian mengenai Optimalisasi Pajak Daerah. sejauh ini teori dan penelitian pendukung yang memadai yang menyentuh masalah substansi sangat sulit didapatkan. Ini perlu dilakukan dalam rangka menjaga eksistensi peran strategis pajak daerah dalam mewujudkan kemandirian keuangan daerah baik di tingkat Kabupaten maupun Perkotaan.

\section{DAFTAR PUSTAKA}

Adelina, R. (2013). Analisis Efektifitas Dan Kontribusi Penerimaan Pajak Bumi Dan Bangunan (Pbb) Terhadap Pendapatan Daerah Di Kabupaten Gresik. Jurnal Kesehatan Olahraga, 1(3), $1-20$.

Affriani. (2018). Strategi Optimalisasi Penerimaan Pajak Reklame Oleh BAPENDA Kota Pekanbaru. 53(9), 1689-1699.

Afrizal. (2015). Metodologi Penelitian Kualitatif. PT Raja Grafindo Persada.

Alisman. (2015). Analisi Faktor-Faktor Yang Mempengaruhi Penerimaan Pajak Hotel di Kabupaten Aceh Barat. Jurnal Ekonomi Dan Kebijakan Publik, 2(6), 183-201.

Asteria, B. (2015). Analisis Pengaruh Penerimaan Pajak Daerah dan Retribusi Daerah Terhadap Pendapatan Asli Daerah Kabupaten/Kota di Jawa Tengah.

Gunawan, I. (2015). Metodologi Penelitian Kualitatif Teori dan Praktik. Bumi Aksara.

Harly, K., \& Afriyenty, M. (2017). Analisis kinerja Pemerintah Daerah Berdasarkan Informasi Finansial Dan Informasi Non-Finansial Pada Kota Solok (Studi Empiris Pada Pemerintah Daerah Kota Solok Tahun 2014-2016). Wra, 5(2), 1065.

Hildawati. (2016). Optimalisasi Penerimaan Daerah Pasca Pengalihan Pajak Bumi Dan Bangunan Perdesaan. Publika, 2(1), 16-29.

Indonesia, R. (2014). Undang-Undang Nomor 23 tahun 2014 tentang Pemerintahan Daerah. In Republik Indonesia.

Kemendagri. (2019). Pedoman Penyusunan APBD.

Keuangan (DJPK), D. J. P. (2018). Ringkasan APBD 2018. November 2017, 2017.

Jati : Jurnal Akuntansi Terapan Indonesia, 2021 | 115 
Mandala Harefa, Sony Hendra Permana, Dewi Restu Mangeswuri, H. M. (2017). Optimalisasi Kebijakan Penerimaan Daerah (C. M. Firdausy (ed.); Ed. 1). Yayasan Pustaka Obor Indonesia. https://books.google.co.id/books?id=N6VeDwAAQBAJ\&pg=PA64\&dq=pengertian + anggar an+berbasis + kinerja\&hl=en\& $s a=X \& v e d=0$ ahUKEwiJ9PSNla7hAhWHknAKHQL6CC0Q6 AEIOTAC $\#_{\mathrm{v}}=$ onepage $\& \mathrm{q}=$ pengertian anggaran berbasis kinerja $\& \mathrm{f}=$ false

Mardiasmo. (2009). Perpajakan. Andi.

Moleong, L. J. (2019). Metodologi Penelitian Kualitatif. PT Remaja Rosda Karya.

Nikho, M. Y. (2010). Analisis Skenario Dampak Penerapan Pajak Rokok terhadap Fiskal Pemerintah dan Perekonomian. FE UI, Program Magister Perencenaan dan Kebijakan Publik, 534.

Putra, P. E. (2010). Efisiensi dan Efektivitas Pengelolaan Keuangan Daerah Pemerintah Kota Solok. Journal of Chemical Information and Modeling, 53(9), 1689-1699.

Putri, P. I. (2013). Analisis Faktor-Faktor Yang Mempengaruhi Penerimaan Pajak. JEJAK (Journal of Economics and Policy), 2(2), 400. https://doi.org/10.22441/mix.2018.v8i2.013.

Republik Indoneisa. (2003). Undang-Undang Nomor 17 Tahun 2003 tentang Keuangan Negara. Republik Indonesia, 2(Undang-Undang Nomor 17 Tahun 2003 tentang Keuangan Negara), 147-173.

Undang-Undang Nomor 28 Tahun 2009 tentang Pajak Daerah dan Retribusi Daerah, Republik Indonesia (2009).

Riduansyah, M. (2003). Kontribusi Pajak Daerah Dan Retribusi Daerah Terhadap Pendapatan Asli Daerah (Pad) Dan Anggaran Pendapatan Dan Belanja Daerah (Apbd) Guna Mendukung Pelaksanaan Otonomi Daerah (Studi Kasus Pemerintah Daerah Kota Bogor). Makara Human Behavior Studies in Asia, 7(2), 49. https://doi.org/10.7454/mssh.v7i2.51

Ritonga, I. (2017). Metoda Penghitungan Potensi PAD. Pustaka Pelajar.

Saputro, D. P. (2018). Faktor - faktor yang mempengaruhi pajak daerah (studi di kabupaten temanggung). Universitas Diponegoro.

Sari, D. P., \& Ilyas, F. (2019). Analisis Faktor-Faktor Yang Mempengaruhi Penerimaan Pajak Daerah Di Provinsi Bengkulu. Jurnal Akuntansi, 6(1), 75-85. https://doi.org/10.33369/j.akuntansi.6.1.75-85

Sari, M. T. (2018). Optimalisasi Pemungutan Pajak Daerah Dalam Rangka Peningkatan Pendapatan Asli Daerah Di Provinsi Lampung. http://digilib.unila.ac.id/29971/3/TESIS TANPA BAB PEMBAHASAN.pdf

Sugiyono. (2012). Metode Penelitian Bisnis. Alfabeta.

Tahwin, M. (2013). Identifikasi Faktor-faktor yang Mempengaruhi Penerimaan Pajak Daerah. Buletin Studi Ekonomi, 18(2), 136-143.

Tohirin. (2016). Metodologi Penelitian Kualitatif dalam Pendidikan dan Bimbingan Konseling. PT Raja Grafindo Persada.

Wardhani, N. E. W. K. (2016). Koordinasi Dinas Pendapatan Daerah Kota Pekanbaru dan Dinas Tata Ruang dan Bangunan Kota Pekanbaru Dalam Menangani Pajak Reklame di Kota Pekanbaru. Jom FISIP, 3(2), 1-9.

Wardhono, A., Indrawati, Y., \& Gema, C. (2012). Kajian Pemetaan dan Optimalisasi Potensi Pajak Dalam Rangka Meningkatkan Pendapatan Asli Daerah (PAD) di Kabupaten Jember. VII(2), 6976.

Wijayanti, W. K. (2010). Faktor-Faktor Yang Mempengaruhi Total Penerimaan Pajak Negara Dan Efektifitas Peraturan Perpajakan. Media Ekonomi, 18(1), 27-40. 